Article

\title{
Anaerobic Digestion of Cigarette Butts: Microbial Community Analysis and Energy Production Estimation
}

\author{
Okkyoung Choi ${ }^{1,+}$, Sae Eun Hwang ${ }^{1,+}$, Hyojung Park ${ }^{2}$ and Byoung-In Sang ${ }^{1, * \text { (D) }}$ \\ 1 Department of Chemical Engineering, Hanyang University, 222 Wangsimni-ro, Seongdong-gu, \\ Seoul 04763, Korea; okgii77@hanyang.ac.kr (O.C.); ds3515@naver.com (S.E.H.) \\ 2 Gwangju Bioenergy R\&D Center, Korea Institute of Energy Research (KIER), 25 Samso-ro, \\ Gwangju 61003, Korea; suya8259@kier.re.kr \\ * Correspondence: biosang@hanyang.ac.kr; Tel.: +82-2-2220-2328 \\ + The first two authors listed share first authorship.
}

check for updates

Citation: Choi, O.; Hwang, S.E.;

Park, H.; Sang, B.-I. Anaerobic

Digestion of Cigarette Butts:

Microbial Community Analysis and

Energy Production Estimation.

Energies 2021, 14, 8290. https:/ /

doi.org/10.3390/en14248290

Academic Editor: Agnieszka Pilarska

Received: 31 October 2021

Accepted: 7 December 2021

Published: 9 December 2021

Publisher's Note: MDPI stays neutral with regard to jurisdictional claims in published maps and institutional affiliations.

Copyright: (c) 2021 by the authors. Licensee MDPI, Basel, Switzerland. This article is an open access article distributed under the terms and conditions of the Creative Commons Attribution (CC BY) license (https:/ / creativecommons.org/licenses/by/ $4.0 /)$.

\begin{abstract}
Anaerobic digestion using cigarette butts, one of most littered items, was studied not only as a waste treatment, but also as an energy production method. Methane production from cigarette butts was measured through the biochemical methane potential (BMP) test and it was evaluated whether it is possible to produce electrical energy. Intact cigarettes or individual components (filter, paper, and leaf) were supplied as the sole carbon source (substrate) for the BMP test. The tendency of methane production indicated biodegradation in the order of paper, filter, and leaves; however, the filter of cigarettes was the substrate produced the highest amount of methane per total solid. The microbial community was also analyzed in each anaerobic digestion reactor, and substrate-specific microorganisms were identified, such as Proteiniphilum strain (filter) and Methanobacterium formicicum (paper). In intact cigarettes, the related microbial community became dominant over time in the order of paper, filter, and leaf. The conversion of cigarette butts to methane, a renewable energy source, can be proposed as a sustainable route for energy demand, for example, in a smoking room.
\end{abstract}

Keywords: cigarette butts; anaerobic digestion; microbial community; methane; waste to energy

\section{Introduction}

Cigarette butts (CBs) are one of the most littered items worldwide. A report published in this regard shows that on International Coastal Cleanup Day in 2017, CBs with plastic filters accounted for the highest quantity (2.4 million), among the trash items collected (Ocean Conservancy). Damage to the ecosystem through CBs has also been reported. CBs reduce the germination and shoot length reached by grass and clover by up to $25 \%$ and reduce the amount of root biomass of clover by almost $60 \%$ [1]. This study indicated that cigarette filters made with cellulose acetate, a biobased plastic filter, may contribute to plant stress [1]. Accordingly, methods for recycling tobacco waste have been proposed. Reports have also been published regarding recycling CBs into high value materials such as cellulose pulp [2] and N-doped carbon powder [3].

However, there are few studies on CBs as an energy source through anaerobic digestion (AD). The end product of anaerobic digestion is biogas, which consists of methane and carbon dioxide. The energy content of the biogas is determined by its high content of methane. Recently, research has been conducted on a method of upgrading biogas (increasing methane composition) by converting surplus power into hydrogen through water electrolysis and using that hydrogen as a reducing agent to convert $\mathrm{CO}_{2}$ into methane [4,5]. The conversion of tobacco to biogas was previously studied using tobacco plants [6] and stalks [7]. The objective of previous studies was primarily to treat tobacco plant waste as agriculture waste. One research reported these as littered items, and the biogas yield was $0.17-0.28 \mathrm{~m}^{3} \mathrm{~kg} \mathrm{TS}^{-1}$ of tobacco [8]. However, it was less than the yield obtained for agricultural residues, such as $0.55-0.62 \mathrm{~m}^{3} \mathrm{~kg} \mathrm{TS}^{-1}$ for rice straw [9], 
0.4-1.0 $\mathrm{m}^{3} \mathrm{~kg} \mathrm{TS}^{-1}$ for maize straw [10], and $0.6 \mathrm{~m}^{3} \mathrm{~kg} \mathrm{TS}^{-1}$ for mango leaves [11]. Since $\mathrm{CB}$ is composed of polymers such as cellulose acetate, the first step in $\mathrm{AD}$, the hydrolysis step, is rate-determining. The cellulose content of CBs has been reported to be $43.4-68.4 \%$ [8]; thus, pretreatment is required to increase the biodegradability of this waste. Other recalcitrant organic matter such as rice straw [12] and pine wood [13] also increase biodegradability and biogas production after pretreatment. Compared to the untreated corn stover, $\mathrm{NaOH}$-pretreated corn stover improves anaerobic biogas production by up to $48.5 \%$ [2].

Research on the anaerobic digestion of CBs has been conducted from the perspective of waste disposal, not from the perspective of energy. In this study, the possible electricity production was predicted by measuring the methane production amount for each element of cigarette butts, and lamp lighting in a smoking room was calculated as an example to see if an energy sustainable system could be constructed through this. The objective of this study was to evaluate the potential of CBs that can be used as an energy source through anaerobic digestion and to analyze the detailed degradation process by investigating the microbial community of $\mathrm{AD}$ fed with $\mathrm{CBs}$ and individual components of $\mathrm{CBs}$; filter, paper, and leaf. Finally, the energy production from $\mathrm{AD}$ with $\mathrm{CBs}$ discarded in the smoking room was estimated.

\section{Materials and Methods}

\subsection{Details of the Tobacco Sample Used}

A single Esse Prime cigarette (KT\&G, South Korea), the most popular cigarette in Korea, containing $4.5 \mathrm{mg}$ tar and $0.45 \mathrm{mg}$ nicotine (based on information provided by the manufacturer) was used. Cigarettes are made up of filters, paper, and leaves (Figure 1). Filters are made of cellulose acetate fibers, a synthetic plastic-like substance. Cellulose acetate is not easily biodegradable and can exist in the environment for more than a decade [14]. Leaves of tobacco plants contain ammonia, volatile fatty acids (VFAs), dextrose, $\mathrm{CaO}, \mathrm{K}_{2} \mathrm{O}, \mathrm{SO}_{4}{ }^{2-}$, and approximately 3000 chemical constituents [15]. Nicotine, cadmium, and lead are representative chemicals classified as harmful or potentially harmful constituents in tobacco products and tobacco smoke in cigarettes by the US Food and Drug Administration in 2012. Generally, a cigarette $(0.52 \mathrm{~g})$ is made of $0.08 \mathrm{~g}(15.4 \%)$ of filter, $0.07 \mathrm{~g}(13.5 \%)$ of paper, and $0.37 \mathrm{~g}(71.2 \%)$ of leaves (Figure 1). To use cigarettes as feedstock in $\mathrm{AD}$ reactors, intact cigarettes or individual components (filters, paper, or leaves) were chopped using a commercial blender (Figure 1). The CBs were presterilized by autoclaving at $121^{\circ} \mathrm{C}$ for $15 \mathrm{~min}$ under $15 \sim 22 \mathrm{psi}$. The sterilization process was also a heat treatment process. Thermal treatment was selected as the pretreatment method to simulate actual smoking on unused cigarettes. After thermal pretreatment, the CBs were prepared at $50 \mathrm{~g} / \mathrm{L}$ in phosphate buffer ( $\mathrm{pH} 7.4,100 \mathrm{mM}$ ).

\subsection{BMP Test}

The biochemical methane production (BMP) test was applied to evaluate methane generation from CBs [16]. The BMP test was performed in a $500 \mathrm{~mL}$ Duran bottle at a working volume of $200 \mathrm{~mL}$. Anaerobic sludge from a municipal wastewater plant (Jungnang, Seoul, South Korea) was added as inoculum $(100 \mathrm{~mL}, \mathrm{pH} 7.4 \pm 0.1$, VFAS $108.3 \pm 25.2 \mathrm{mg} / \mathrm{L}$, alkalinity $5.9 \pm 0.8 \mathrm{~g} / \mathrm{L}$ as $\mathrm{CaCO}_{3}$, TS $22.6 \pm 0.02 \%$, VS $70.7 \pm 1.04 \%$ ) in autoclaved bottles and $100 \mathrm{~mL}$ of CBs solution prepared at $50 \mathrm{~g} / \mathrm{L}$ in phosphate buffer $(100 \mathrm{mM}, \mathrm{pH} 7.4)$ was used. Final cigarette concentration for the BMP test was $25 \mathrm{~g} / \mathrm{L}$. The VS ratio of inoculum to substrate was between 3.2 and 4.0. After confirming that there was no indigenous biogas production, CBs were injected as the sole carbon source. To achieve anaerobic conditions, all bottles were purged with argon (Ar) gas for $30 \mathrm{~min}$. All bottles were prepared in duplicates and incubated at $37^{\circ} \mathrm{C}$ with mild agitation at $150 \mathrm{rpm}$. The biogas production was monitored daily using a sterile syringe, to equilibrate the pressure within the bottle with atmospheric pressure. It was run as a batch system and the experiment ended when no biogas was released. Average AD period was $43 \pm 7.5$ day. The biogas component was 
analyzed by gas chromatography-thermal conductivity detection (GC-TCD) (6500GC System, YL Instruments, Korea), and the final biogas content was determined by multiplying the volume and fractional percentage.

$$
\text { Methane production }(\mathrm{mL})=\text { biogas volume }(\mathrm{mL}) \times \text { Methane fraction }(\%)
$$

The $\mathrm{pH}$ and the VFAs, total carbon (TC), and total inorganic carbon (IC) content were analyzed every three days. Total organic carbon (TOC) was calculated by subtracting IC from TC.
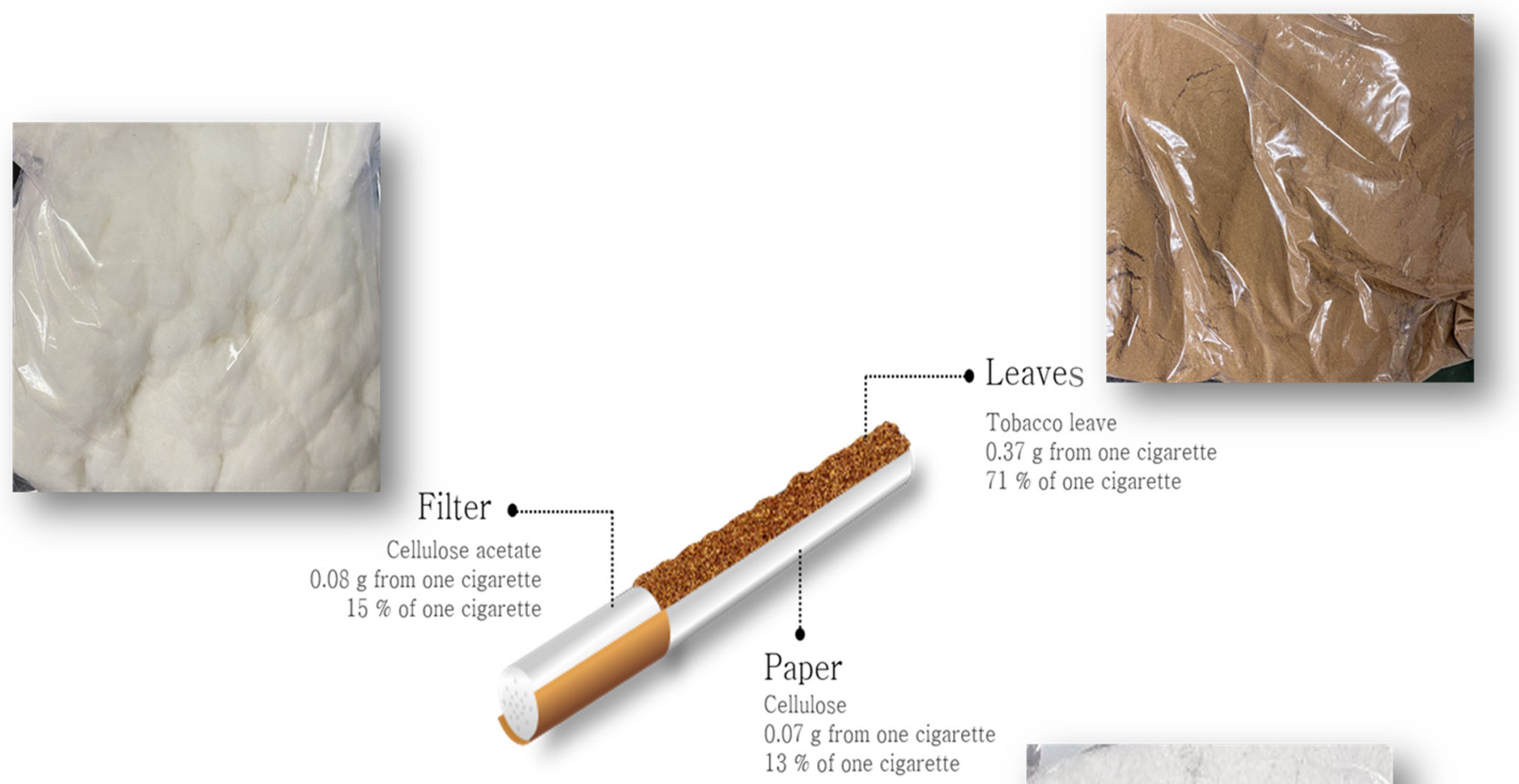

Figure 1. Cigarette composition used for anaerobic digestion. The inserted pictures show the powder after the chopping process.

\subsection{Analytical Methods}

The gas composition was analyzed by GC-TCD (gas chromatography-thermal conductivity detector) with a Carboxen ${ }^{\circledR}-1006$ PLOT capillary GC column (Supelco, L $\times$ I.D. $30 \mathrm{~m} \times 0.32 \mathrm{~mm}$, average thickness $15 \mu \mathrm{m}$ ) using carrier Ar (flow rate $2 \mathrm{~mL} / \mathrm{min}$ ) and oven, injector, and detector temperatures of 60,230 , and $230{ }^{\circ} \mathrm{C}$, respectively. The $\mathrm{pH}$ was measured using a meter (HI11310, Hanna instrument, Woonsocket, RI, USA). Total organic carbon (TOC) was determined by TOC-L (total organic carbon analyzer, Shimadzu, Kyoto, Japan). Volatile fatty acid (VFAS) concentrations were measured by gas chromatographyflame ionization detection (GC-FID, 6890N, Agilent Technologies, Santa Clara, CA, USA) equipped with RESTECK Stabilwax $\left(30 \mathrm{~m} \times 0.25 \mu \mathrm{m} \times 0.25 \mu \mathrm{m}\right.$ ) using carrier $\mathrm{N}_{2}$ (flow rate $2 \mathrm{~mL} / \mathrm{min}$ ) with $5 \mathrm{~m}$ of intraguard. The temperature of the oven, injector, and detector 
were 50,250 , and $250^{\circ} \mathrm{C}$. VFAS production was calculated from maximum VFAS concentration analyzed by GC-FID. Volatile solid (VS) was determined following EPA method 1684. All data are expressed as average \pm standard deviation.

\subsection{Modified Gompertz Model}

The modified Gompertz model is one of most commonly applied kinetic models in batch tests [17].

$$
V_{C H_{4}}(t)=P \times \exp \left\{-\exp \left[\frac{R_{\max } \exp (1)}{P}(\lambda-t)+1\right]\right\}
$$

In Equation (2), $\mathrm{V}_{\mathrm{CH} 4}(\mathrm{t})$ is the cumulative methane production $(\mathrm{mL})$ at a given time $t(h) . R_{\max }$ is the maximum specific methane production rate $(\mathrm{mL} / \mathrm{h}) . \mathrm{P}$ is the methane production potential (mL) and $\lambda$ is the lag phase time (h) [18]. Anaerobic digestion (AD) period was calculated using the modified Gompertz model equation, up to time indicating less than $10 \%$ of methane production potential. The period excluded the lag phase.

\subsection{Microbial Community Analysis}

DNA was extracted from $0.5 \mathrm{~g}$ of each sample using a Fast DNA ${ }^{\mathrm{TM}}$ Spin Kit for soil (MP Biomedicals, LLC, Solon, OH, USA), according to the manufacturer's protocol. The concentration of extracted double stranded DNA was determined using an Infinite M200 PRO microplate reader (Tecan Austria GmbH, Grödig, Austria). The DNA was then stored in a freezer at $-27{ }^{\circ} \mathrm{C}$ for further analyses. Amplification of the V3-V4 region of the bacterial $16 \mathrm{~S}$ rRNA gene was performed for each sample using $341 \mathrm{~F}$ and 805R primers. Samples were amplified for Illumina platform using a forward and reverse fusion primer. The forward primer was constructed with the $\left(5^{\prime}-3^{\prime}\right)$ Nextera consensus (TCGTCGGCAGCGTC), a sequencing adaptor (AGATGTGTATAAGAGACAG), and the appropriate forward primer selected for the bacterial diversity assay (341F: CCTACGGGNGGCWGCAG) [19]. The reverse fusion primer was constructed with the $\left(5^{\prime}-3^{\prime}\right)$ Nextera consensus (GTCTCGTGGGCTCGG), a sequencing adaptor, and the appropriate reverse primer for the bacterial diversity assay (805R: GACTACHVGGGTATCTAATCC) [19]. To detect methanogen species, Arch519F (CAGCCGCCGCGGTAA) and Arch934R (GTGCTCCCCCGCCAATTC) were used as methanogen-specific primers [20]. Amplifications were performed in a reaction volume of $25 \mu \mathrm{L}$, containing Dr. MAX DNA polymerase (Doctor Protein Inc., Korea), 10 pmol of each primer, and $1 \mu \mathrm{L}$ of template. Reactions were carried out using the following thermal profile: $95^{\circ} \mathrm{C}$ for $3 \mathrm{~min}$, then 25 cycles at $95{ }^{\circ} \mathrm{C}$ for $30 \mathrm{~s}$ each, $55^{\circ} \mathrm{C}$ for $30 \mathrm{~s}, 72{ }^{\circ} \mathrm{C}$ for $30 \mathrm{~s}$, followed by one cycle at $72{ }^{\circ} \mathrm{C}$ for $5 \mathrm{~min}$. DNA sequencing was performed by ChunLab, Inc. (Seoul, Korea) using an Illumina/MiSeq platform (San Diego, CA, USA), according to the manufacturer's protocol.

Raw sequence reads from each biogas plant sample were processed, and the compositions and proportions of bacteria and methanogens in shared sets of multiple samples were analyzed using CLcommunity (Version 3.46, Chunlab Inc., Seoul, Korea). Each sequencing read was processed and taxonomically assigned using the EzTaxon e-database [21]. Typical taxonomic suffixes were "_s" for species, and "Unclassified taxons" were indicated with _uc [22]. The overall phylogenetic distance among communities was estimated using the unweighted pair group method with arithmetic mean (UPGMA) clustering $[23,24]$. Bacterial community distribution at the phylum and species level matrix was visualized using Circos [25]. Sequencing reads generated in this study are available in the EMBL SRA database under the accession number PRJNA664880.

\section{Results and Discussion}

\subsection{Data for BMP Test}

Methane production was normalized using the division by total solids (TS) (Figure 2). VS ratios of filter, paper, and leaves were $99.7 \%, 80.0 \%$, and $86.7 \%$, respectively (ash pictures after VS measurement are shown in Figure S1). The amount of methane was 
presented as accumulated methane production from $\mathrm{AD}$. Methane production with each of the cigarette constituents was as follows: filter- $545.8 \mathrm{NmL} / \mathrm{g}$ TS (547.4 NmL/g VS), paper-391.7 NmL/g TS (489.6 NmL/g VS), and leaves-162.2 NmL/g TS (187.1 NmL/g VS) $(p<0.05$, Figure 2 and Table 1$)$. The methane production value of the whole cigarette was much less than the sum of individual methane production multiplied by the composition ratio. To simplify final energy calculations, methane production per total solids is shown. The consumption rate of VFAS can determine the residual VFAS concentration, and the measured concentration might not show actual VFAS production, but with the maximum concentration analyzed, VFAS production was the highest in leaves $(820.5 \mathrm{mg} / \mathrm{g}$ TS), followed by that in paper $(374.3 \mathrm{mg} / \mathrm{g})$, and filter $(132.9 \mathrm{mg} / \mathrm{g})$. However, it refers to net production and does not represent actual total production. All VFAS produced from the total cigarette, filter and paper was consumed and finally converted to biogas, but not all VFAS produced from leaves was consumed (Figure S2). TOC removal efficiency was found to be the highest in paper $(75.5 \%)$, followed by that in filters $(59.4 \%)$ and leaves $(50.3 \%)$ (Table 1). The time profiles of VFAS, TC, TOC, and IC are shown in Supplementary Materials as Figures S2 and S3. The VS concentration was in the order of filter (99.7\%), leaves $(86.7 \%)$, and paper $(80.0 \%)$, and paper showed a higher organic carbon removal rate compared to the VS concentration it contained. Cellulose acetate in filters is generally regarded as a biodegradable plastic [26]. Tobacco, an agriculture and household waste, has been reported as a low methane-producing material [8]. A study on the codigestion of tobacco stalks, wheat stalks, and pig manure showed $163 \mathrm{~L} \mathrm{CH}_{4} / \mathrm{kg}$ VS (volatile solid) at $35^{\circ} \mathrm{C}$ [7]. Another study reported $53.84 \mathrm{~L} \mathrm{CH}_{4} / \mathrm{kg}$ fresh tobacco, obtained for the mixture of $15 \%$ tobacco/ $85 \%$ water with a hydraulic retention time of 16 days [6]. Methane production from intact cigarettes was $137.8 \mathrm{~mL} / \mathrm{g}$ TS, in our batch test (Table 1). The methane content was $51.4-56 \%$ (Table 1). Theoretical composition of methane in biogas is related to the mean oxidation state of carbon in the specific substrate [27]. Based on the methane content of intact cigarettes, the mean oxidation state of carbon in intact cigarettes was found to be similar to that of phenyl alanine $\left(-0.44\right.$ carbon oxidation state, $\left.56 \% \mathrm{CH}_{4}\right)$ and insulin $\left(-0.08,51 \% \mathrm{CH}_{4}\right)$ [27].

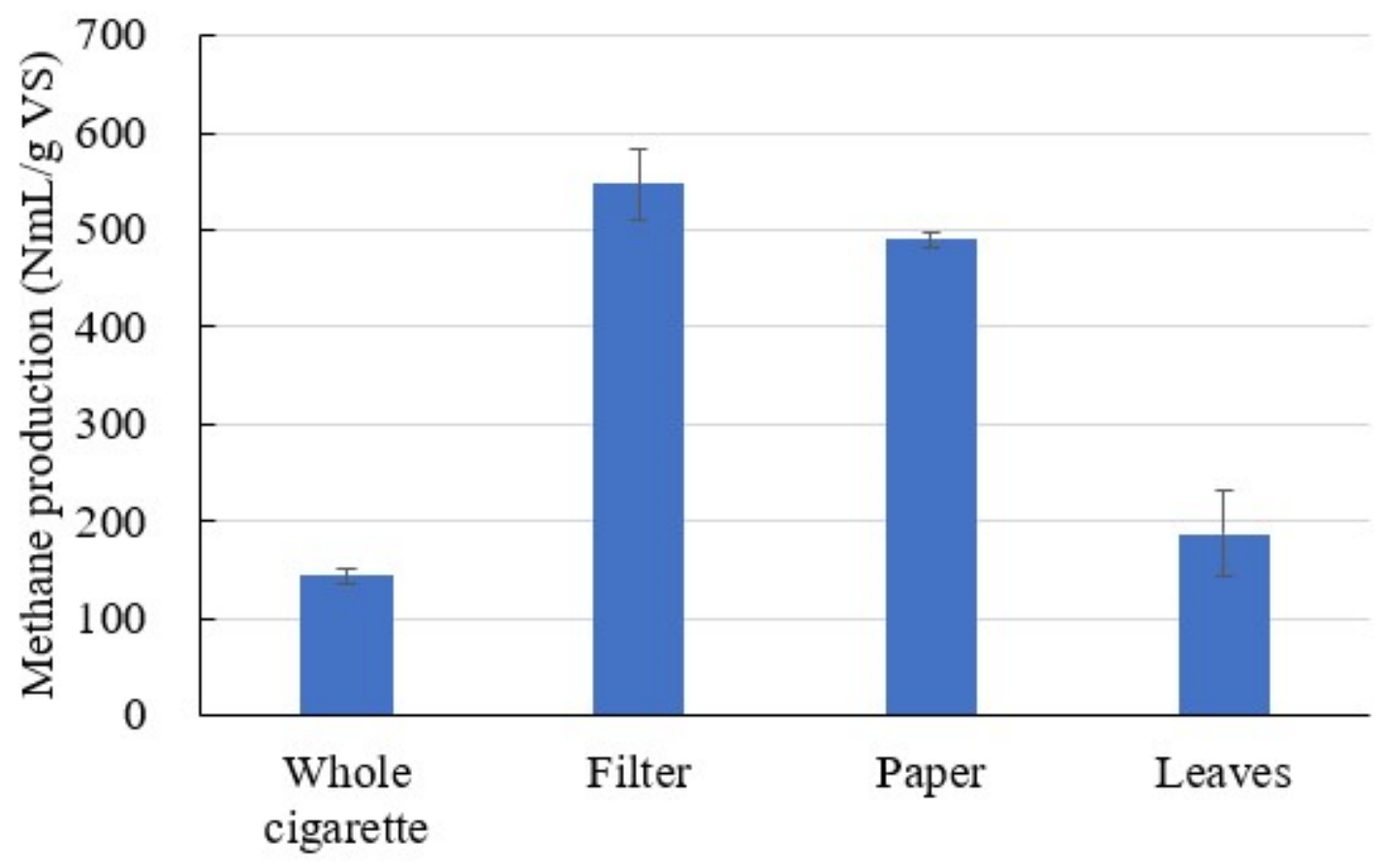

Figure 2. Amount of methane produced by each component of cigarette butts. Methane production was normalized using the division by volatile solids (VS). 
Table 1. Results of anaerobic digestion using cigarette butts or individual components and kinetic parameters calculated from the modified Gompertz model. All data are expressed as mean \pm standard deviation.

\begin{tabular}{|c|c|c|c|c|c|}
\hline \multirow{2}{*}{$\begin{array}{l}\text { Results of Anaerobic } \\
\text { Digestion }\end{array}$} & \multicolumn{2}{|c|}{ Total Methane Production } & \multirow{2}{*}{$\begin{array}{l}\text { VFAS Production } \\
\text { (mg/g TS *) }\end{array}$} & \multirow{2}{*}{$\begin{array}{c}\text { TOC Removal } \\
(\%)\end{array}$} & \multirow{2}{*}{$\begin{array}{c}\text { Methane Content } \\
(\%)\end{array}$} \\
\hline & $(\mathrm{NmL} / \mathrm{g}$ TS *) & (NmL/g VS) & & & \\
\hline Whole cigarette & $126.2( \pm 7.0)$ & $143.8( \pm 7.9)$ & $357.4( \pm 17.8)$ & $53.0( \pm 2.6)$ & $56.0( \pm 0.6)$ \\
\hline Filter & $545.8( \pm 36.7)$ & $547.4( \pm 36.8)$ & $132.9( \pm 19.3)$ & $59.4( \pm 4.1)$ & $56.6( \pm 1.1)$ \\
\hline Paper & $391.7( \pm 6.8)$ & $489.6( \pm 8.5)$ & $374.3( \pm 8.9)$ & $75.5( \pm 3.6)$ & $56.7( \pm 0.7)$ \\
\hline Leaves & $162.2( \pm 38.7)$ & $187.1( \pm 44.6)$ & $820.5( \pm 32.8)$ & $50.3( \pm 6.3)$ & $51.4( \pm 3.8)$ \\
\hline \multirow{2}{*}{$\begin{array}{c}\text { Results of Modified } \\
\text { Gompertz Model } \\
\text { Applied }\end{array}$} & \multicolumn{2}{|c|}{$\begin{array}{l}\text { Methane Production Potential } \\
\text { (BMP) }\end{array}$} & \multirow{2}{*}{$\begin{array}{c}\text { Maximum Specific } \\
\text { Methane Production } \\
\text { Rate }\left(\mathbf{R}_{\max }, \mathrm{mL} / \mathrm{hr} / \mathrm{g} \mathrm{TS} *\right)\end{array}$} & \multirow{2}{*}{$\begin{array}{l}\text { Lag Phase Time } \\
(\lambda, \mathrm{hr})\end{array}$} & \multirow{2}{*}{ AD Period ** (hr) } \\
\hline & $(\mathrm{NmL} / \mathrm{g}$ TS *) & (NmL/g VS) & & & \\
\hline Whole cigarette & 139.6 & 159.0 & 0.17 & 98.1 & 1300 \\
\hline Filter & 405.8 & 407.1 & 0.49 & 225.3 & 875.5 \\
\hline Paper & 237.9 & 297.4 & 0.30 & 50.2 & 864.2 \\
\hline Leaves & 7.6 & 88.7 & 0.09 & 551.5 & 1100.8 \\
\hline
\end{tabular}

* The results were normalized by dividing by the injected feedstock mass. The methane volume is expressed as values at room temperature $\left(25 \pm 3^{\circ} \mathrm{C}\right)$ and atmospheric pressure. ${ }^{* *}$ The period was calculated using the modified Gompertz model equation, up to the time indicating less than $10 \%$ of methane production potential (BMP) and the lag phase time was subtracted from the period. The amount of feedstock was $5 \mathrm{~g}$.

To understand $\mathrm{AD}$ with intact cigarettes, experimental data were applied for the modified Gompertz model (see Supplementary Materials, Figure S4, for details). The methane production potential of intact cigarettes was found to be $152.4 \mathrm{~mL} / \mathrm{TS}$. The highest methane production potential of $443.0 \mathrm{~mL} / \mathrm{g}$ TS was observed for the filter compartment of cigarettes. The filter of the cigarette is the part that is leftover in the highest quantity after smoking, and it contributes the most to the production of methane from CBs.

The ease of biodegradability of the substrate can be judged by the duration of the lag phase. The lag phase duration, analyzed using the modified Gompertz model, increased in the following order: paper $(50.2 \mathrm{~h})$, filter $(225.3 \mathrm{~h})$, and leaves $(551.5 \mathrm{~h})$. However, the lag phase shortened or disappeared with repeated batches (data not shown). The enriched microbiome could reduce the duration of the anaerobic process because an augmented microbiome could shorten a lag phase and abundant CBs-degrading microorganisms could increase the degradation rate.

\subsection{Microbiome}

\subsubsection{Bacterial Community}

Figure 3 shows the UPGMA clustering of the bacterial community in the sample fed as intact cigarettes and as individual components. The results showed that the initial bacterial community of the intact cigarette sample was similar to that of the paper-only sample, but the final community of the intact cigarette sample was similar to that of the leaf-only sample (Figure 3). Bacterial community analysis also showed that the biodegradation process occurred in the order of paper, filter, and leaf, as indicated by the methane production delay time (Table 1).

At the phylum level, Bacteroides dominated the bacterial community of filter and paper-fed AD, whereas Firmicutes dominated the leaf-fed AD (Figure 4a). Proteiniphilum FJ189548_s was mostly found in filter-fed AD (Figure 4b and Table 2). Proteiniphilum was isolated from a propionate-degrading mixture, which used yeast extract and peptone as the energy source, producing acetate and propionate [28]. Proteiniphilum is also found in cellulose-fed microbial fuel cells and degrades polysaccharides and xylans to simple organic compounds, such as acetate and succinate [29-32]. Bacterial community in paper-fed AD showed more diversity than in filter-fed AD (Figure 4 b). Proteolytic bacteria such as Petrimonas mucosa, Bacteroides graminisolvens, and Aminobacterium mobile were dominant in paper-fed AD (Table 2). The isolation of Petrimonas mucosa and Bacteroides graminisolvens from biogas reactors $[33,34]$ and Aminobacterium mobile from an anaerobic lagoon 
has been reported [35]. Petrimonas mucosa has weak extracellular enzyme activity against cellulose [33]. Bacteroides graminisolvens utilize cellobiose, but not cellulose [34]. Proteolytic bacteria such as the Bacillus spp. and Arthrobacter spp., isolated from an agricultural waste treatment plant, are able to degrade intact feathers [36]. The protein content in coarse tobacco waste has been reported to be in the range $2.7-4.8 \%$, whereas carbohydrates and minerals contribute $25-50 \%$ and $12-45 \%$, respectively, to the tobacco waste [8]. However, bacterial community analysis revealed that proteolytic bacteria were dominant, irrespective of the substrate composition. The predominance of proteolytic bacteria in filter/paper-fed $\mathrm{AD}$ suggests that proteolytic bacteria play an important role in the AD of CBs. The abundance of proteolytic strains in a system fed with paper were reported in a metaproteomics study and suggested a possible correlation between cellulose methanation and proteolytic activity [37].

Leaf-fed AD comprised a unique bacterial community. In this sample, a variety of species were found without a largely dominant species (Figure $4 \mathrm{~b}$ and Table 2). Aminobacterium mobile, Clostridium celatum, Paraclostridium benzoelyticum, Clostridium butyricum, Cloacamonas acidaminovorans, and Escherichia coli were found in leaf-fed AD. Clostridium butyricum, a fermentative bacterium, was found only in leaf-fed $\mathrm{AD}$ among individual leaf, paper, and filter (Table 2).

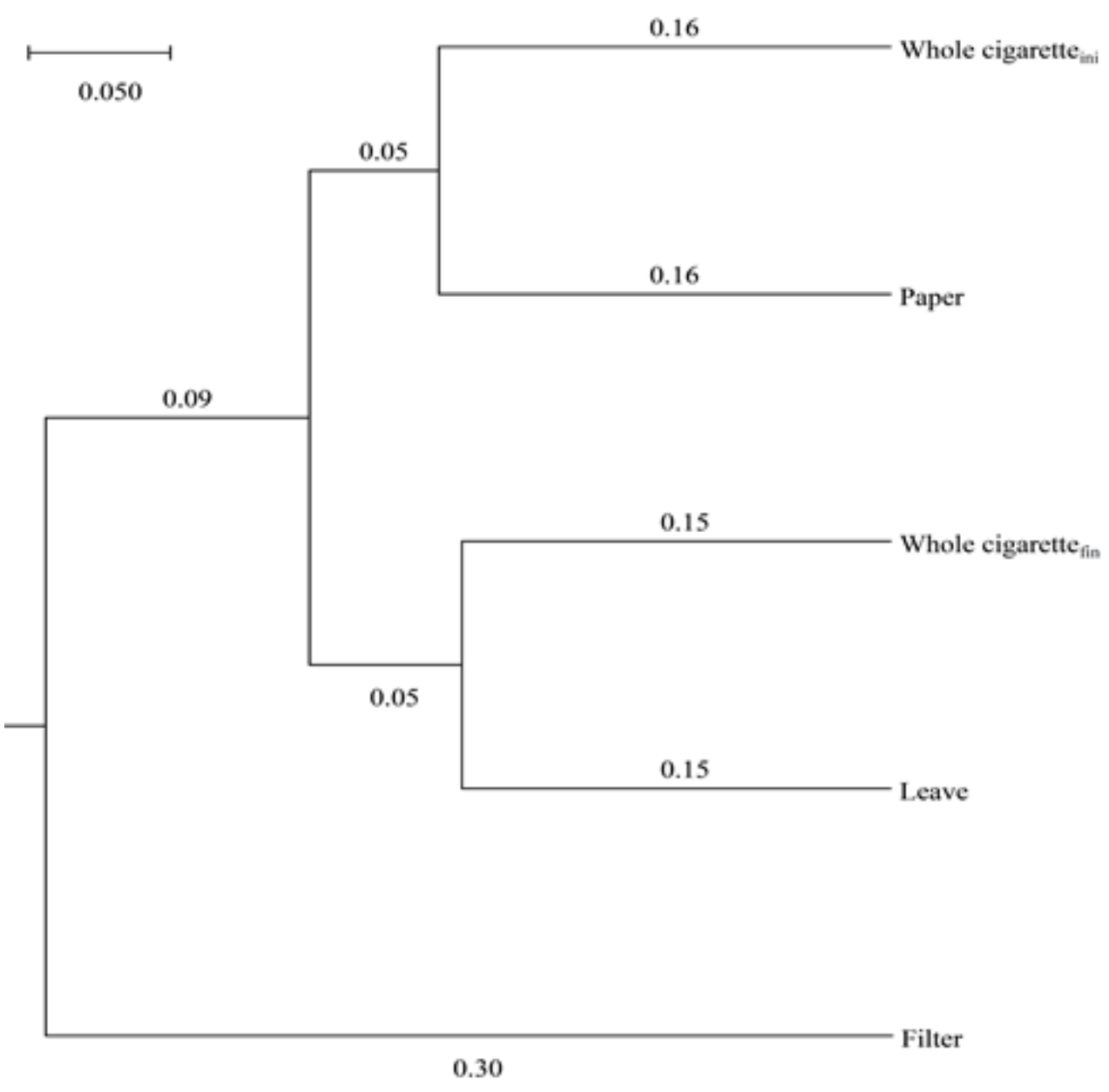

Figure 3. UPGMA clustering of bacterial microbes fed intact cigarettes or individual components for anaerobic digestion. 


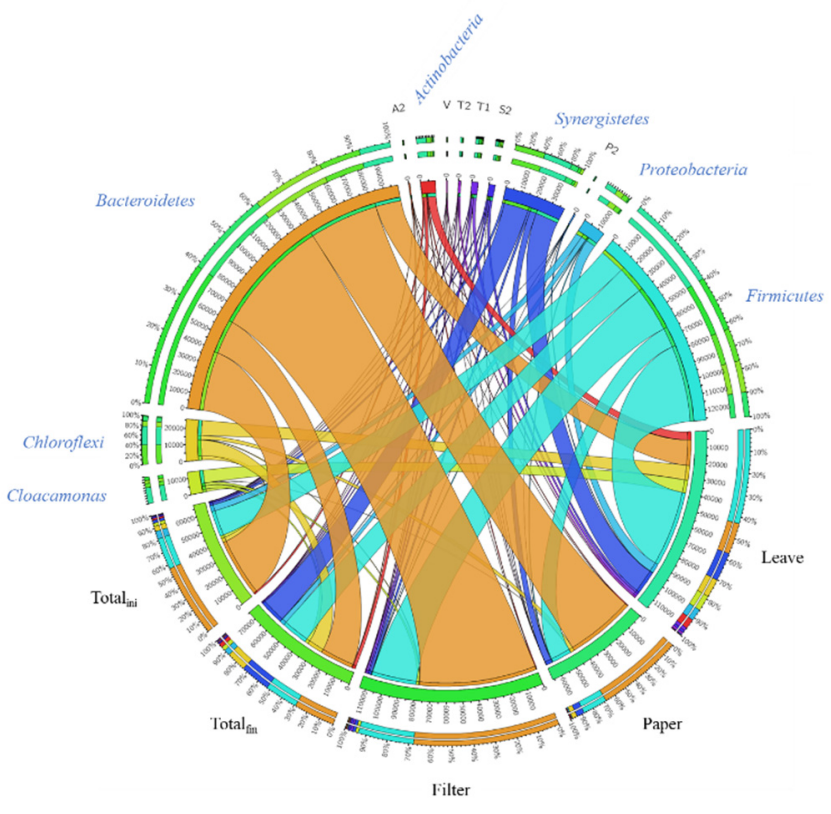

(a)

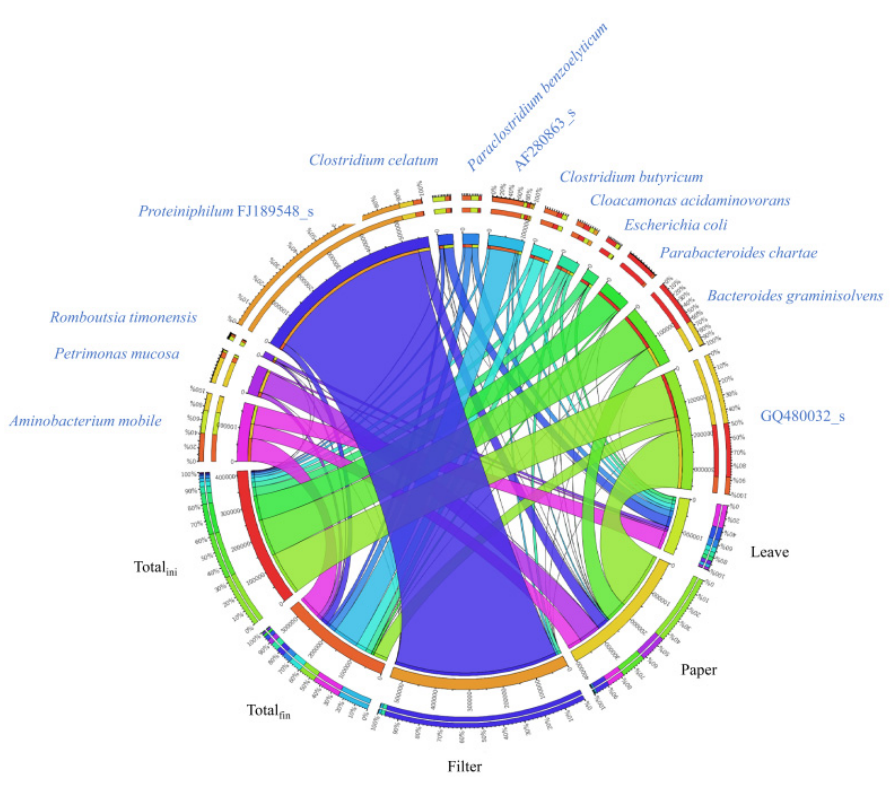

(b)

Figure 4. Circos representation of bacterial communities from the anaerobic digestion of intact cigarettes or individual components as: (a) phylum level; (b) species level.

Table 2. Bacterial microbes (species level) in an AD reactor fed cigarette butts or individual components. Numbers represent the distribution as percentage at the species level, and the column colors indicate high distribution in the three components: pink (filter), paper (yellow), and leaf (green).

\begin{tabular}{|c|c|c|c|c|c|c|c|}
\hline Taxon Name & $\begin{array}{c}\text { Whole } \\
\text { Cigarette }_{\text {ini }}\end{array}$ & $\begin{array}{c}\text { Whole } \\
\text { Cigarette }_{\text {fin }}\end{array}$ & Filter & Paper & Leaf & $\begin{array}{c}\text { Isolation } \\
\text { Source/Identification }\end{array}$ & $\begin{array}{l}\text { Supposed } \\
\text { Substrate }\end{array}$ \\
\hline GQ480032_s & 13.72 & 4.38 & 0.00 & 18.00 & 0.02 & $\begin{array}{l}\text { Only reported gene } \\
\text { sequence (analysis of } \\
\text { bacterial community } \\
\text { changes during } \\
\text { sewage treated } \\
\text { process, unpublished, } \\
\text { Genbank: } \\
\text { GQ480032.1) }\end{array}$ & Paper \\
\hline $\begin{array}{l}\text { Bacteroides } \\
\text { graminisol- } \\
\text { vens }\end{array}$ & 11.69 & 0.12 & 0.00 & 6.64 & 0.04 & $\begin{array}{l}\text { Xylanolytic anaerobe } \\
\text { isolated from a } \\
\text { methanogenic reactor } \\
\text { treating cattle } \\
\text { waste [34] }\end{array}$ & Paper \\
\hline $\begin{array}{l}\text { Parabacteroides } \\
\text { chartae }\end{array}$ & 7.86 & 0.68 & 0.00 & 0.06 & 0.02 & $\begin{array}{c}\text { Isolated from } \\
\text { wastewater of a paper } \\
\text { mill [38] }\end{array}$ & \\
\hline $\begin{array}{l}\text { Escherichia } \\
\text { coli }\end{array}$ & 2.72 & 0.11 & 0.00 & 0.11 & 1.08 & & Leaf \\
\hline $\begin{array}{l}\text { Cloacamonas } \\
\text { acidaminovo- } \\
\text { rans }\end{array}$ & 1.70 & 1.95 & 1.03 & 0.02 & 1.21 & $\begin{array}{l}\text { Proteolytic anaerobes } \\
\qquad[39]\end{array}$ & Filter, Leaf \\
\hline $\begin{array}{l}\text { Clostridium } \\
\text { butyricum }\end{array}$ & 1.32 & 3.42 & 0.00 & 0.00 & 1.30 & $\begin{array}{c}\text { Fermentative } \mathrm{H}_{2} \\
\text { production [40] }\end{array}$ & Leaf \\
\hline AF280863_s & 0.81 & 8.10 & 0.65 & 0.41 & 0.84 & $\begin{array}{l}\text { Isolated from a } \\
\text { bioreactor treating } \\
\text { pharmaceutical } \\
\text { wastewater [41] }\end{array}$ & \\
\hline
\end{tabular}


Table 2. Cont.

\begin{tabular}{|c|c|c|c|c|c|c|c|}
\hline Taxon Name & $\begin{array}{c}\text { Whole } \\
\text { Cigarette }_{\text {ini }}\end{array}$ & $\begin{array}{c}\text { Whole } \\
\text { Cigarette }_{\text {fin }}\end{array}$ & Filter & Paper & Leaf & $\begin{array}{c}\text { Isolation } \\
\text { Source/Identification } \\
\end{array}$ & $\begin{array}{l}\text { Supposed } \\
\text { Substrate }\end{array}$ \\
\hline $\begin{array}{l}\text { Paraclostridium } \\
\text { benzoelyticum }\end{array}$ & 0.69 & 2.23 & 0.00 & 0.00 & 2.00 & $\begin{array}{c}\text { Isolated from marine } \\
\text { sediment [42] }\end{array}$ & Leaf \\
\hline $\begin{array}{c}\text { Clostridium } \\
\text { celatum }\end{array}$ & 0.31 & 1.08 & 0.03 & 0.06 & 3.14 & $\begin{array}{c}\text { Isolated from normal } \\
\text { human feces [43] }\end{array}$ & Leaf \\
\hline $\begin{array}{l}\text { Proteiniphilum } \\
\text { FJ189548_s }\end{array}$ & 0.22 & 2.06 & 51.89 & 3.58 & 0.03 & $\begin{array}{c}\text { Belonging to } \\
\text { Proteiniphilum } \\
\text { proteolytic genus [28] }\end{array}$ & Filter, paper \\
\hline $\begin{array}{l}\text { Romboutsia } \\
\text { timonensis }\end{array}$ & 0.12 & 0.48 & 0.04 & 0.13 & 1.01 & $\begin{array}{l}\text { Isolated from human } \\
\text { gut [44] }\end{array}$ & Leaf \\
\hline $\begin{array}{l}\text { Petrimonas } \\
\text { mucosa }\end{array}$ & 0.09 & 1.41 & 0.04 & 6.78 & 0.57 & $\begin{array}{c}\text { Isolated from } \\
\text { anaerobic reactor fed } \\
\text { with maize silage and } \\
\text { pig and cattle } \\
\text { manure [33] }\end{array}$ & Paper \\
\hline $\begin{array}{l}\text { Aminobacterium } \\
\text { mobile }\end{array}$ & 0.06 & 7.23 & 0.00 & 4.43 & 5.87 & $\begin{array}{c}\text { Amino } \\
\text { acid-degrading } \\
\text { bacteria [35] }\end{array}$ & Paper, leaf \\
\hline
\end{tabular}

\subsubsection{Archaeal Community}

Strains of methanogens were highly dependent on the substrate (Figure 5). Hydrogenotrophic methanogen was mostly dominant; however, in filter-fed AD, Methanosaeta concilii, an acetoclastic methanogen, was dominant (Figure 5 and Table 3). Methanosaeta spp., a potential indicator for anaerobic conversion of long-chain fatty acids to methane [45], and Methanosaeta concilii have been identified as the main methanogens present in a full-scale anaerobic bioreactor treating paper mill wastewater [46]. Interestingly, Methanobacterium formicicum was highly dominant $(77.72 \%$ ) in paper-fed AD (Table 3). M. formicicum has been found during $\mathrm{AD}$ in the presence of long chain fatty acids [47] even though it can utilize the low carbon such as $\mathrm{CO}_{2}$ and formate [48] and has been described as the $\mathrm{H}_{2}$-utilizing partner of the VFAS-degrading microbiome [49]. There was no significant difference in the types of volatile fatty acids among filter, paper, leaf-fed AD (Figure S2). The reason for the dominance of $M$. formicicum in paper-fed $\mathrm{AD}$ remains unknown, but the coculture of M. formicicum with anaerobic fungi shows high production of cellulolytic and xylanolytic enzymes [50]. In this study, Methanobacterium congolense was present at $22.68 \%$ in leaf-fed AD (Table 3). Methanobacterium congolense was earlier isolated from the AD reactor of cassava peel [51] and also found in a biogas plant with low VFAS concentration $(<500 \mathrm{ppm})$ [52]. It has also been used to study the conversion of low-concentration $\mathrm{CO}_{2}$ to $\mathrm{CH}_{4}$ [53]. Methanogens acting on intact cigarettes were predominantly uncultured Methanosarcina species (denoted as Methanosarcina_uc in Figure 5 and Table 3). These species are capable of using various compounds $\left(\mathrm{H}_{2} / \mathrm{CO}_{2}\right.$, acetate, formate/methanol) as the energy source $[54,55]$; hence, it is difficult to determine the main substrate in intact cigarettes. 


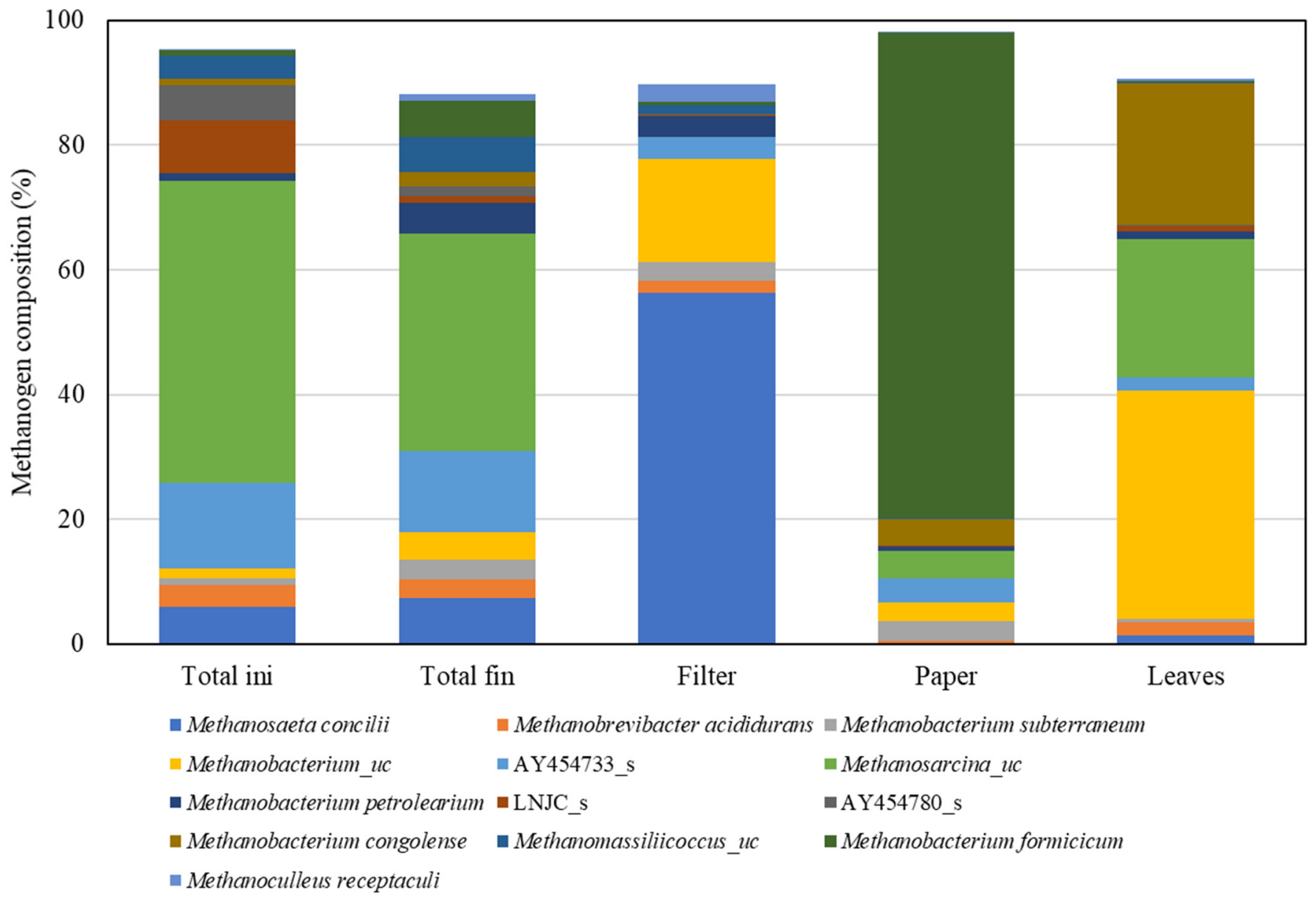

Figure 5. Methanogen distribution at the species level in anaerobic digestion reactor fed intact cigarettes or individual components.

Table 3. Methanogens in an AD reactor fed cigarette butts or individual components.

\begin{tabular}{|c|c|c|c|c|c|c|}
\hline Taxon Name & $\begin{array}{c}\text { Whole } \\
\text { Cigarette }_{\text {ini }}\end{array}$ & $\begin{array}{c}\text { Whole } \\
\text { Cigarette }_{\text {fin }}\end{array}$ & Filter & Paper & Leaf & Methanogen Type \\
\hline Methanosarcina_uc & 48.35 & 34.92 & 0.80 & 4.40 & 22.08 & \\
\hline Methanosaeta concilii & 6.02 & 7.40 & 56.30 & 0.10 & 1.45 & Acetoclastic [56] \\
\hline $\begin{array}{c}\text { Methanobrevibacter } \\
\text { acididurans }\end{array}$ & 3.43 & 3.01 & 1.90 & 0.34 & 1.96 & Hydrogenotrophic [56] \\
\hline Methanobacterium_uc & 1.63 & 4.38 & 16.46 & 2.91 & 36.56 & \\
\hline $\begin{array}{l}\text { Methanobacterium } \\
\text { petrolearium }\end{array}$ & 1.27 & 4.86 & 3.33 & 0.76 & 1.29 & Hydrogenotrophic [57] \\
\hline $\begin{array}{l}\text { Methanobacterium } \\
\text { congolense }\end{array}$ & 1.15 & 2.35 & 0.04 & 4.35 & 22.68 & Hydrogenotrophic [51] \\
\hline $\begin{array}{l}\text { Methanobacterium } \\
\text { subterraneum }\end{array}$ & 1.06 & 3.18 & 3.06 & 3.31 & 0.60 & Hydrogenotrophic [58] \\
\hline $\begin{array}{l}\text { Methanobacterium } \\
\text { formicicum }\end{array}$ & 0.87 & 5.68 & 0.55 & 77.72 & 0.12 & Hydrogenotrophic [59] \\
\hline Methanobacterium palustre & 0.76 & 1.85 & 0.68 & 0.54 & 0.27 & Hydrogenotrophic [60] \\
\hline $\begin{array}{c}\text { Methanobacterium } \\
\text { beijingense }\end{array}$ & 0.76 & 3.90 & 1.64 & 0.39 & 0.54 & Hydrogenotrophic [61] \\
\hline Methanoculleus receptaculi & 0.23 & 1.11 & 2.81 & 0.00 & 0.32 & Hydrogenotrophic [62] \\
\hline $\begin{array}{c}\text { Methanobrevibacter } \\
\text { boviskoreani }\end{array}$ & 0.00 & 0.01 & 0.00 & 0.00 & 2.25 & Hydrogenotrophic [63] \\
\hline $\begin{array}{l}\text { Methanosphaera } \\
\text { stadtmanae }\end{array}$ & 0.23 & 0.14 & 0.33 & 0.02 & 2.16 & Hydrogenotrophic [64] \\
\hline
\end{tabular}




\subsection{Estimation of Energy Conversion in Methane Production from CBs}

The methane production from intact cigarettes or individual components was analyzed, and the modified Gompertz model was applied to determine the methane production potential (Table 1). The values obtained were used to calculate the energy produced from the AD of CBs. (Table 4). Methane production was calculated after considering the weight of $500 \mathrm{CBs}$ after smoking. The weight of each part of the cigarette thrown away after smoking was assumed as $1 / 10$ for the leaf, $3 / 10$ for the paper, and the filter part as it was. The methane production potential is the result of the modified Gompertz model applied to $\mathrm{AD}$ using individual cigarette components (Table 4). The coefficient for converting methane to energy was $9.4 \mathrm{Wh} / \mathrm{L} \mathrm{CH}_{4}$, which was used to convert methane production energy into electrical energy [65]. The median value of the power of light bulbs (32-40 W) in a smoking room; $36 \mathrm{~W}$ was used as the power of the lighting bulb. Based on the calculations, electrical energy produced was sufficient to light the bulb for $5.7 \mathrm{~h}$ (Table 4, see Supplementary Materials for detailed calculation). This result shows the possibility of waste being recycled as energy through the process of $\mathrm{AD}$, together with disposing $\mathrm{CBs}$, which are the most littered item.

Table 4. Energy calculation estimated from methane production from cigarette butts leftover in a smoking room.

\begin{tabular}{|c|c|c|c|c|}
\hline \multicolumn{2}{|c|}{ Cigarette Butt after Smoking (g) } & $\begin{array}{l}\text { Assumed Waste Weight, If } \\
500 \text { Cigarette Butts per Day }\end{array}$ & $\begin{array}{c}\text { Methane Production } \\
\text { Potential, }\left(\mathrm{mL} \mathrm{CH}_{4} / \mathrm{g} \text { TS) }\right.\end{array}$ & $\begin{array}{l}\text { Methane Production } \\
\left(\mathrm{mL} \mathrm{CH}_{4}\right)\end{array}$ \\
\hline Filter & 0.08 & 40 & 443 & 17720 \\
\hline Paper & 0.02 & 10 & 259.7 & 2597 \\
\hline Leaf & 0.04 & 20 & 83.9 & 1678 \\
\hline \multicolumn{4}{|c|}{ Daily Methane Production (L/day) } & 22.0 \\
\hline \multirow{4}{*}{\multicolumn{3}{|c|}{ Energy Conversion to Electricity }} & 9.4 & Wh/L methane * \\
\hline & & & 206.8 & Wh \\
\hline & & & 36 & W bulb \\
\hline & & & 5.7 & $\mathrm{hr}$ \\
\hline
\end{tabular}

* The value was referred from IRENA report [65].

\section{Conclusions}

The production of methane from CBs by AD is a promising method to dispose of the most wasted items worldwide and convert this waste into energy. Particularly, it is a component discarded after smoking, and the filter made of cellulose acetate showed the most methane production per TS. Proteolytic bacteria were dominant in the AD of CBs, and the enriched microbiome rapidly produced methane after the lag period. Thus, using a local feedstock such as CBs in a smoking room, we envision a sustainable system by gaining energy from methane production through wastes.

Supplementary Materials: The following are available online at https:/ / www.mdpi.com/article / 10.3390/en14248290/s1, Figure S1: The pictures of paper, leaves, and filter after VS measurement. The photo shows the ash remaining after burning $6 \mathrm{~g}$ TS each at $550{ }^{\circ} \mathrm{C}$., Figure S2: Time profile of volatile fatty acid concentrations with total $\mathrm{CB}$ or each component as a substrate for biochemical methane potential test., Figure S3: Time profile of total carbon (TC), total organic carbon (TOC), and inorganic carbon (IC) with total CB or each component as a substrate for biochemical methane potential test., Figure S4: The modified Gompertz model depending on the kinds of substrates as: (a) ground tobacco, (b) ground filter, (c) ground paper, (d) ground leaf. Spots show experimental values and lines indicate modeling predictions.

Author Contributions: Conceptualization, B.-I.S. and O.C.; methodology, S.E.H.; software, O.C.; validation, H.P., O.C., and B.-I.S.; formal analysis, S.E.H.; data curation, H.P.; writing-original draft preparation, O.C.; writing-review and editing, B.-I.S.; visualization, O.C.; supervision, B.-I.S. All authors have read and agreed to the published version of the manuscript.

Funding: This research was funded by the Korea Institute of Energy Technology Evaluation and Planning (KETEP) and the Ministry of Trade, Industry and Energy (MOTIE) of the Republic of Korea (No. 2019281010007B) and a grant from the "Graduate School of Post Plastic Specialization," a part 
of the Korea Environmental Industry and Technology Institute, which was funded by the Ministry of Environment, Republic of Korea. This work also received support in part by a grant funded by Hanyang University in the Republic of Korea (HY-201100000000233-N).

Institutional Review Board Statement: Not applicable.

Informed Consent Statement: Not applicable.

Data Availability Statement: Sequencing reads generated in this study are available in the EMBL SRA database under the accession number PRJNA664880 at https:/ / www.ncbi.nlm.nih.gov / bioproject/ PRJNA664880.

Conflicts of Interest: The authors declare no conflict of interest.

\section{References}

1. Green, D.S.; Boots, B.; Da Silva Carvalho, J.; Starkey, T. Cigarette butts have adverse effects on initial growth of perennial ryegrass (gramineae: Lolium perenne L.) and white clover (leguminosae: Trifolium repens L.). Ecotoxicol. Environ. Saf. 2019, $182,109418$. [CrossRef]

2. D’heni Teixeira, M.B.; Duarte, M.A.B.; Raposo Garcez, L.; Camargo Rubim, J.; Hofmann Gatti, T.; Suarez, P.A.Z. Process development for cigarette butts recycling into cellulose pulp. Waste Manag. 2017, 60, 140-150. [CrossRef]

3. Yu, C.; Hou, H.; Liu, X.; Han, L.; Yao, Y.; Dai, Z.; Li, D. The recovery of the waste cigarette butts for N-doped carbon anode in lithium ion battery. Front. Mater. 2018, 5. [CrossRef]

4. Baena-Moreno, F.M.; Zhang, Z.; Zhang, X.P.; Reina, T.R. Profitability analysis of a novel configuration to synergize biogas upgrading and Power-to-Gas. Energy Convers. Manag. 2020, 224, 113369. [CrossRef]

5. Collet, P.; Flottes, E.; Favre, A.; Raynal, L.; Pierre, H.; Capela, S.; Peregrina, C. Techno-economic and Life Cycle Assessment of methane production via biogas upgrading and power to gas technology. Appl. Energy 2017, 192, 282-295. [CrossRef]

6. González-González, A.; Cuadros, F.; Ruiz-Celma, A.; López-Rodríguez, F. Potential application of anaerobic digestion to tobacco plant. Fuel 2013, 113, 415-419. [CrossRef]

7. Liu, Y.; Dong, J.; Liu, G.; Yang, H.; Liu, W.; Wang, L.; Kong, C.; Zheng, D.; Yang, J.; Deng, L.; et al. Co-digestion of tobacco waste with different agricultural biomass feedstocks and the inhibition of tobacco viruses by anaerobic digestion. Biores. Technol. 2015, 189, 210-216. [CrossRef]

8. Meher, K.K.; Panchwagh, A.M.; Rangrass, S.; Gollakota, K.G. Biomethanation of tobacco waste. Environ. Pollut. 1995, 90, 199-202. [CrossRef]

9. Polprasert, C.; Edwards, P.; Rajput, V.; Pacharaprakiti, C. Integrated biogas technology in the tropics 1. Performance of small-scale digesters. Waste Manag. Res. 1986, 4, 197-213. [CrossRef]

10. Deublein, D.; Steinhauser, A. Biogas from Waste and Renewable Resources: An Introduction; John Wiley \& Sons: Hoboken, NJ, USA, 2011.

11. Shyam, M.; Sharma, P.K. Solid-state anaerobic digestion of cattle dung and agro-residues in small-capacity field digesters. Biores. Technol. 1994, 48, 203-207. [CrossRef]

12. He, Y.; Pang, Y.; Liu, Y.; Li, X.; Wang, K. Physicochemical characterization of rice straw pretreated with sodium hydroxide in the solid state for enhancing biogas production. Energy Fuels 2008, 22, 2775-2781. [CrossRef]

13. Salehian, P.; Karimi, K.; Zilouei, H.; Jeihanipour, A.J.F. Improvement of biogas production from pine wood by alkali pretreatment. Fuel 2013, 106, 484-489. [CrossRef]

14. Benavente, M.; Arevalo Caballero, M.J.; Silvero, G.; López-Coca, I.; Escobar, V. Cellulose acetate recovery from cigarette butts. Proceedings 2019, 2, 1447. [CrossRef]

15. Leffingwell, J.C. Chemical Constituents of Tobacco Leaf and Differences among Tobacco Types; Elsevier: Amsterdam, The Netherlands, 2001; pp. 173-232.

16. Filer, J.; Ding, H.; Chang, S. Biochemical Methane Potential (BMP) assay method for anaerobic digestion research. Water 2019, 11, 921. [CrossRef]

17. Etuwe, C.N.; Momoh, Y.O.L.; Iyagba, E.T. Development of mathematical models and application of the modified gompertz model for designing batch biogas reactors. Waste Biomass Valori. 2016, 7, 543-550. [CrossRef]

18. Nguyen, D.D.; Chang, S.W.; Jeong, S.Y.; Jeung, J.; Kim, S.; Guo, W.; Ngo, H.H. Dry thermophilic semi-continuous anaerobic digestion of food waste: Performance evaluation, modified Gompertz model analysis, and energy balance. Energ. Convers. Manag. 2016, 128, 203-210. [CrossRef]

19. Fadrosh, D.W.; Ma, B.; Gajer, P.; Sengamalay, N.; Ott, S.; Brotman, R.M.; Ravel, J. An improved dual-indexing approach for multiplexed 16S rRNA gene sequencing on the Illumina MiSeq platform. Microbiome 2014, 2, 6. [CrossRef]

20. Song, H.; Choi, O.; Pandey, A.; Kim, Y.G.; Joo, J.S.; Sang, B.-I. Simultaneous production of methane and acetate by thermophilic mixed culture from carbon dioxide in bioelectrochemical system. Biores. Technol. 2019, 281, 474-479. [CrossRef] [PubMed]

21. Chun, J.; Lee, J.-H.; Jung, Y.; Kim, M.; Kim, S.; Kim, B.K.; Lim, Y.-W. EzTaxon: A web-based tool for the identification of prokaryotes based on $16 S$ ribosomal RNA gene sequences. Int. J. Syst. Evol. Microbiol. 2007, 57, 2259-2261. [CrossRef] 
22. Kim, O.-S.; Cho, Y.-J.; Lee, K.; Yoon, S.-H.; Kim, M.; Na, H.; Park, S.-C.; Jeon, Y.S.; Lee, J.-H.; Yi, H.; et al. Introducing EzTaxon-e: A prokaryotic $16 \mathrm{~S}$ rRNA gene sequence database with phylotypes that represent uncultured species. Int. J. Syst. Evol. Microbiol. 2012, 62, 716-721. [CrossRef]

23. Sneath, P.H.; Sokal, R.R. Numerical Taxonomy. The Principles and Practice of Numerical Classification; CABI: Wallingford, UK, 1973.

24. Hur, I.; Chun, J. A method for comparing multiple bacterial community structures from 16S rDNA clone library sequences. J. Microbiol. 2004, 42, 9-13.

25. Krzywinski, M.; Schein, J.; Birol, I.; Connors, J.; Gascoyne, R.; Horsman, D.; Jones, S.J.; Marra, M.A. Circos: An information aesthetic for comparative genomics. Genome Res. 2009, 19, 1639-1645. [CrossRef]

26. Ach, A. Biodegradable plastics based on cellulose acetate. J. Macromol. Sci. A 1993, 30, 733-740. [CrossRef]

27. Van Lier, J.B.; Mahmoud, N.; Zeeman, G. Anaerobic wastewater treatment. In Biological Wastewater Treatment: Principles, Modelling Design; IWA Publishing: London, UK, 2008; pp. 415-456.

28. Chen, S.; Dong, X. Proteiniphilum acetatigenes gen. nov., sp. nov., from a UASB reactor treating brewery wastewater. Int. J. Syst. Evol. Microbiol. 2005, 55, 2257-2261. [CrossRef]

29. Hodgson, D.M.; Smith, A.; Dahale, S.; Stratford, J.P.; Li, J.V.; Grüning, A.; Bushell, M.E.; Marchesi, J.R.; Avignone Rossa, C. Segregation of the anodic microbial communities in a microbial fuel cell cascade. Front. Microbiol. 2016, 7, 699. [CrossRef] [PubMed]

30. Li, W.; Quan, X.; Chen, L.; Zheng, Y. Application of slow-release carbon sources embedded in polymer for stable and extended power generation in microbial fuel cells. Chemosphere 2020, 244, 125515. [CrossRef]

31. Toczyłowska-Mamińska, R.; Szymona, K.; Król, P.; Gliniewicz, K.; Pielech-Przybylska, K.; Kloch, M.; Logan, B.E. Evolving microbial communities in cellulose-fed microbial fuel cell. Energies 2018, 11, 124. [CrossRef]

32. Tomazetto, G.; Hahnke, S.; Wibberg, D.; Pühler, A.; Klocke, M.; Schlüter, A. Proteiniphilum saccharofermentans str. M3/6T isolated from a laboratory biogas reactor is versatile in polysaccharide and oligopeptide utilization as deduced from genome-based metabolic reconstructions. Biotechnol. Rep. 2018, 18, e00254. [CrossRef] [PubMed]

33. Hahnke, S.; Langer, T.; Koeck, D.E.; Klocke, M. Description of Proteiniphilum saccharofermentans sp. nov., Petrimonas mucosa sp. nov. and Fermentimonas caenicola gen. nov., sp. nov., isolated from mesophilic laboratory-scale biogas reactors, and emended description of the genus Proteiniphilum. Int. J. Syst. Evol. Microbiol. 2016, 66, 1466-1475. [CrossRef]

34. Nishiyama, T.; Ueki, A.; Kaku, N.; Watanabe, K.; Ueki, K. Bacteroides graminisolvens sp. nov., a xylanolytic anaerobe isolated from a methanogenic reactor treating cattle waste. Int. J. Syst. Evol. Microbiol. 2009, 59, 1901-1907. [CrossRef]

35. Baena, S.; Fardeau, M.-L.; Labat, M.; Ollivier, B.; Garcia, J.-L.; Patel, B. Aminobacterium mobile sp. nov., a new anaerobic amino-acid-degrading bacterium. Int. J. Syst. Evol. Microbiol. 2000, 50, 259-264. [CrossRef]

36. Nnolim, N.E.; Okoh, A.I.; Nwodo, U.U. Proteolytic bacteria isolated from agro-waste dumpsites produced keratinolytic enzymes. Biotechnol. Rep. 2020, 27, e00483. [CrossRef] [PubMed]

37. Lü, F.; Bize, A.; Guillot, A.; Monnet, V.; Madigou, C.; Chapleur, O.; Mazéas, L.; He, P.; Bouchez, T. Metaproteomics of cellulose methanisation under thermophilic conditions reveals a surprisingly high proteolytic activity. ISME J. 2014, 8, 88-102. [CrossRef]

38. Tan, H.-Q.; Li, T.-T.; Zhu, C.; Zhang, X.-Q.; Wu, M.; Zhu, X.-F. Parabacteroides chartae sp. nov., an obligately anaerobic species from wastewater of a paper mill. Int. J. Syst. Evol. Microbiol. 2012, 62, 2613-2617. [CrossRef] [PubMed]

39. Pelletier, E.; Kreimeyer, A.; Bocs, S.; Rouy, Z.; Gyapay, G.; Chouari, R.; Rivière, D.; Ganesan, A.; Daegelen, P.; Sghir, A.; et al. "Candidatus Cloacamonas acidaminovorans": Genome sequence reconstruction provides a first glimpse of a new bacterial division. J. Bacteriol. 2008, 190, 2572-2579. [CrossRef]

40. Chen, W.-M.; Tseng, Z.-J.; Lee, K.-S.; Chang, J.-S. Fermentative hydrogen production with Clostridium butyricum CGS5 isolated from anaerobic sewage sludge. Int. J. Hydrogen Energy 2005, 30, 1063-1070. [CrossRef]

41. LaPara, T.M.; Nakatsu, C.H.; Pantea, L.; Alleman, J.E. Phylogenetic analysis of bacterial communities in mesophilic and thermophilic bioreactors treating pharmaceutical wastewater. Appl. Environ. Microbiol. 2000, 66, 3951-3959. [CrossRef] [PubMed]

42. Sasi Jyothsna, T.S.; Tushar, L.; Sasikala, C.; Ramana, C.V. Paraclostridium benzoelyticum gen. nov., sp. nov., isolated from marine sediment and reclassification of Clostridium bifermentans as Paraclostridium bifermentans comb. nov. Proposal of a new genus Paeniclostridium gen. nov. to accommodate Clostridium sordellii and Clostridium ghonii. Int. J. Syst. Evol. Microbiol. 2016, $66,1268-1274$.

43. Hauschild, A.H.W.; Holdeman, L.V. Clostridium celatum sp.nov., isolated from normal human feces. Int. J. Syst. Evol. Microbiol. 1974, 24, 478-481. [CrossRef]

44. Ricaboni, D.; Mailhe, M.; Khelaifia, S.; Raoult, D.; Million, M. Romboutsia timonensis, a new species isolated from human gut. New Microbes New Infect. 2016, 12, 6-7. [CrossRef]

45. Silva, S.A.; Salvador, A.F.; Cavaleiro, A.J.; Pereira, M.A.; Stams, A.J.M.; Alves, M.M.; Sousa, D.Z. Toxicity of long chain fatty acids towards acetate conversion by Methanosaeta concilii and Methanosarcina mazei. Microb. Biotechnol. 2016, 9, 514-518. [CrossRef]

46. Roest, K.; Heilig, H.G.H.J.; Smidt, H.; de Vos, W.M.; Stams, A.J.M.; Akkermans, A.D.L. Community analysis of a full-scale anaerobic bioreactor treating paper mill wastewater. Syst. Appl. Microbiol. 2005, 28, 175-185. [CrossRef]

47. Sousa, D.Z.; Salvador, A.F.; Ramos, J.; Guedes, A.P.; Barbosa, S.; Stams, A.J.M.; Alves, M.M.; Pereira, M.A. Activity and viability of methanogens in anaerobic digestion of unsaturated and saturated long-chain fatty acids. Appl. Environ. Microbiol. 2013, 79, 4239-4245. [CrossRef] [PubMed] 
48. Chellapandi, P.; Bharathi, M.; Sangavai, C.; Prathiviraj, R. Methanobacterium formicicum as a target rumen methanogen for the development of new methane mitigation interventions: A review. Vet. Anim. Sci. 2018, 6, 86-94. [CrossRef] [PubMed]

49. Stantscheff, R.; Kuever, J.; Rabenstein, A.; Seyfarth, K.; Dröge, S.; König, H. Isolation and differentiation of methanogenic Archaea from mesophilic corn-fed on-farm biogas plants with special emphasis on the genus Methanobacterium. Appl. Microbiol. Biot. 2014, 98, 5719-5735. [CrossRef]

50. Teunissen, M.J.; Kets, E.P.; Op den Camp, H.J.; Huis in't Veld, J.H.; Vogels, G.D. Effect of coculture of anaerobic fungi isolated from ruminants and non-ruminants with methanogenic bacteria on cellulolytic and xylanolytic enzyme activities. Arch. Microbiol. 1992, 157, 176-182. [CrossRef] [PubMed]

51. Cuzin, N.; Ouattara, A.S.; Labat, M.; Garcia, J.L. Methanobacterium congolense sp. nov., from a methanogenic fermentation of cassava peel. Int. J. Syst. Evol. Microbiol. 2001, 51, 489-493. [CrossRef]

52. Tejerizo, G.T.; Kim, Y.S.; Maus, I.; Wibberg, D.; Winkler, A.; Off, S.; Pühler, A.; Scherer, P.; Schlüter, A. Genome sequence of Methanobacterium congolense strain Buetzberg, a hydrogenotrophic, methanogenic archaeon, isolated from a mesophilic industrial-scale biogas plant utilizing bio-waste. J. Biotechnol. 2017, 247, 1-5. [CrossRef]

53. Chen, X.; Ottosen, L.D.M.; Kofoed, M.V.W. How low can you go: Methane production of Methanobacterium congolense at low $\mathrm{CO}_{2}$ concentrations. Front. Bioeng. Biotechnol. 2019, 7. [CrossRef]

54. Mah, R.A.; Smith, M.R.; Baresi, L. Studies on an acetate-fermenting strain of Methanosarcina. Appl. Environ. Microbiol. 1978, 35, 1174-1184. [CrossRef]

55. Mah, R.A.; Kuenen, J.G.; Quayle, J.R. Methanogenesis and Methanogenic Partnerships. Biol. Sci. 1982, $297,599-616$.

56. Patel, G.B.; Sprott, G.D. Methanosaeta concilii gen. nov., sp. nov. ("Methanothrix concilii") and Methanosaeta thermoacetophila nom. rev., comb. nov. Int. J. Syst. Evol. Microbiol. 1990, 40, 79-82. [CrossRef]

57. Mori, K.; Harayama, S. Methanobacterium petrolearium sp. nov. and Methanobacterium ferruginis sp. nov., mesophilic methanogens isolated from salty environments. Int. J. Syst. Evol. Microbiol. 2011, 61, 138-143. [CrossRef]

58. Kotelnikova, S.; Macario, A.J.; Pedersen, K. Methanobacterium subterraneum sp. nov., a new alkaliphilic, eurythermic and halotolerant methanogen isolated from deep granitic groundwater. Int. J. Syst. Bacteriol. 1998, 48, 357-367. [CrossRef]

59. Battumur, U.; Yoon, Y.-M.; Kim, C.-H. Isolation and characterization of a new Methanobacterium formicicum KOR-1 from an anaerobic digester using pig slurry. Asian-Aust. J. Anim. Sci. 2016, 29, 586-593. [CrossRef] [PubMed]

60. Zellner, G.; Bleicher, K.; Braun, E.; Kneifel, H.; Tindall, B.J.; de Macario, E.C.; Winter, J. Characterization of a new mesophilic, secondary alcohol-utilizing methanogen, Methanobacterium palustre spec. nov. from a peat bog. Arch. Microbiol. 1988, 151, 1-9. [CrossRef]

61. Ma, K.; Liu, X.; Dong, X. Methanobacterium beijingense sp. nov., a novel methanogen isolated from anaerobic digesters. Int. J. Syst. Evol. Microbiol. 2005, 55, 325-329. [CrossRef]

62. Cheng, L.; Qiu, T.L.; Li, X.; Wang, W.D.; Deng, Y.; Yin, X.B.; Zhang, H. Isolation and characterization of Methanoculleus receptaculi sp. nov. from Shengli oil field, China. FEMS Microbiol. Lett. 2008, 285, 65-71. [CrossRef]

63. Lee, J.H.; Kumar, S.; Lee, G.H.; Chang, D.H.; Rhee, M.S.; Yoon, M.H.; Kim, B.C. Methanobrevibacter boviskoreani sp. nov., isolated from the rumen of Korean native cattle. Int. J. Syst. Evol. Microbiol. 2013, 63, 4196-4201. [CrossRef] [PubMed]

64. Miller, T.L.; Wolin, M.J. Methanosphaera stadtmaniae gen. nov., sp. nov.: A species that forms methane by reducing methanol with hydrogen. Arch. Microbiol. 1985, 141, 116-122. [CrossRef]

65. IRENA. Measuring Small-Scale Biogas Capacity and Production; IRENA: Abu Dhabi, United Arab Emirates, 2016. 